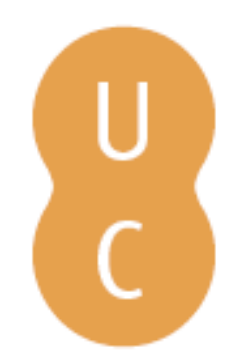

\title{
pommalina
}

\section{Kinismo: fragmentos de uma crítica}

Autor(es): $\quad$ Loureiro, João Diogo R. P. G.

Publicado por: Imprensa da Universidade de Coimbra

URL persistente:

URI:http://hdl.handle.net/10316.2/34713

DOI:

DOI:http://dx.doi.org/10.14195/978-989-721-042-6_13

Accessed : $\quad$ 26-Apr-2023 16:32:45

A navegação consulta e descarregamento dos títulos inseridos nas Bibliotecas Digitais UC Digitalis, UC Pombalina e UC Impactum, pressupõem a aceitação plena e sem reservas dos Termos e Condições de Uso destas Bibliotecas Digitais, disponíveis em https://digitalis.uc.pt/pt-pt/termos.

Conforme exposto nos referidos Termos e Condições de Uso, o descarregamento de títulos de acesso restrito requer uma licença válida de autorização devendo o utilizador aceder ao(s) documento(s) a partir de um endereço de IP da instituição detentora da supramencionada licença.

Ao utilizador é apenas permitido o descarregamento para uso pessoal, pelo que o emprego do(s) título(s) descarregado(s) para outro fim, designadamente comercial, carece de autorização do respetivo autor ou editor da obra.

Na medida em que todas as obras da UC Digitalis se encontram protegidas pelo Código do Direito de Autor e Direitos Conexos e demais legislação aplicável, toda a cópia, parcial ou total, deste documento, nos casos em que é legalmente admitida, deverá conter ou fazer-se acompanhar por este aviso. 


\section{Dos Homens e suas Ideias \\ Estudos sobre as Vidas de Diógenes Laércio}

Delfim Leão, Gabriele Cornelli \& Miriam C. Peixoto (coords.) 


\title{
Kinismo: Fragmentos de uma Crítica ${ }^{1}$ KYNICISM: FRAGMENTS OF A CRITIQUE
}

\author{
JoÃo Diogo R. P. G. Loureiro \\ Universidade de Coimbra - Centro de Estudos Clássicos e Humanísticos
}

\begin{abstract}
Resumo: Este artigo é composto por dois ensaios. O primeiro centra-se na oposição kínica à razão e à filosofia. Defendemos que, apesar do kinismo ter correctamente intuído a inevitável incapacidade da razão para apreender o todo da realidade, não conseguiu perceber que a mundivisão kínica, com a sua concepção atada de natureza, também deixa de lado parte importante da nossa experiência fenomenológica. A ideia kínica de escolher viver de acordo com a natureza é também alvo fértil de críticas, pondo-se a nu a imagem errónea da vontade humana que lhe subjaz. O segundo ensaio questiona o ideal de auto-suficiência que o kínico quer atingir. Mostra-se que não consegue cumprir com ele, pelo contrário: ele procura o público e depende dos mesmos códigos sociais que desrespeita. A autarkeia, defendemos, é fundamentalmente falsa, porque ignora as pessoas como elas são: seres relacionais, dependentes e frágeis.

Palavras-chave: kinismo, Diógenes de Sínope, razão e vontade, vida de acordo com a natureza, autarkeia
\end{abstract}

Aвstract: This paper comprises two essays. The first one focuses on the war waged by the kynics against reason and philosophy. It argues that, although kynicism correctly sensed the inevitable inability of reason to capture the whole of reality, it failed to notice that the kynic outlook too, with its straightjacketed understanding of nature, leaves aside an important part of our phenomenological experience. The kynic idea of choosing to live in accordance with nature is also subject to severe criticism, laying bare the erroneous image of human will that underpins it. The second essay questions the ideal of self-sufficiency at which the kynic aims. It is shown that he does not live up to it,

${ }^{1} \mathrm{O}$ presente trabalho era originalmente constituído por mais um ensaio, dedicado às relações entre o kinismo e as ciências e as artes, que, entre outras por razões de espaço, aqui não reproduzimos. Inseridos no projecto de tradução de Diógenes Laércio (doravante, para evitar a confusão, Laércio apenas), servimo-nos sobretudo, para a nossa reflexão, do Livro VI, o que não nos impediu de trazer, quando oportuno, outros testemunhos à colação. Centrámos, mas não reduzimos, a nossa discussão na figura de Diógenes de Sínope, não apenas por ser aquele, dentro do movimento kínico, a que Laércio dedica mais páginas, mas sobretudo por ser o seu fundador (concordamos com a maioria dos críticos neste particular, não descurando, todavia, a importância de Antístenes, que também convocamos, como proto-kínico). Onde, na indicação de passos, não for mencionada a obra, é a Laércio que nos referimos (usámos a edição teubneriana de Marcovich). Todas as traduções são nossas, salvo indicação em contrário e os textos de Luciano, para os quais nos socorremos das edições de autor de Custódio Magueijo (reedição em curso nos Classica Digitalia). Por fim, como o título deixa entender, acolhemos aqui a proveitosa distinção de Sloterdijk (o nosso principal interlocutor) entre kinismo e cinismo, que põe cobro a um malentendido irritante, ainda que o chamado cinismo clássico seja apenas o momento inaugural, reconhecido e consciente, do primeiro, sendo, nesse sentido, impróprio usar o termo 'kinismo' para nos referirmos a ele [cinismo antigo] apenas. 
rather on the contrary: he is in search of an audience and hinges on the very social codes he disrespects. Autarkeia, we argue, is ultimately false, because it ignores what persons are: relational, dependent and fragile beings.

Keywords: kynicism, Diogenes of Sinope, reason and will, life according to nature, autarkeia

\section{$\S 1$}

O kinismo figura em todas as histórias da filosofia, mas é, parece-nos, mister interrogarmo-nos sobre a justeza deste reconhecimento. Mais do que uma filosofia completa, ele aparece-nos como um modo de vida, uma Lebensart. Se toda a filosofia digna do nome não pode deixar de enfrentar o problema da ética (como devo agir?), não se resume, todavia, a este, contra o que pretendem os kínicos (6.103), que nisso confessam a sua parcialidade. Não serve um conjunto de máximas ou crias ilustrativas da vida boa, se carentes de fundamentação, sem um logos que justifique as opções morais preconizadas. Já na Antiguidade o estatuto do kinismo como escola não era, de facto, consensual (veja-se a defesa vincada de Laércio da sua posição em 6.103, como quem sente a necessidade de se justificar), em parte pela vagueza se não mesmo vazio dogmático do movimento ${ }^{2}$. Hegel é honesto, e por isso severo, no seu juízo, nas Liçôes Sobre a História da Filosofia: "Diógenes é famoso tão-só pelo seu modo de vida; nele, tal como nos kínicos tardios, o kinismo adquire o sentido mais de um simples modo de vida do que de uma filosofia” (1975 558). E logo na primeira linha da sua análise da escola, o mestre de Iena escreve: "os kínicos têm pouca formação filosófica e nunca chegaram à elaboração de um sistema, de uma ciência” (1975 551). Veremos que, em parte, esse salto nunca foi dado por vontade dos próprios, pelo segredo triste que expuseram: a fraqueza de toda a teoria para lidar com o real. Diógenes, suspeitamos, agradeceria que o excluíssemos dos manuais de filosofia, ele que se apresenta como o paladino de uma anti-filosofia do óbvio.

É significativa uma dupla anedota narrada por Laércio (6.39): "A alguém que argumentava por silogismos ${ }^{3}$ que ele tinha cornos, [Diógenes,] tendo apalpado a testa, disse: «eu, porém, não vejo [nada]». Do mesmo modo, também [em resposta] a alguém que dizia que não havia movimento, levantando-se, deu umas voltas". Diógenes desfaz aqui os paradoxos de duas importantes escolas: os megarenses e os eleatas. Lembra-nos Samuel Johnson, que, questionado por Boswell acerca da doutrina de Berkeley, terá dado um valente pontapé numa pedra, exclamando: "I refute it thus". Estórias destas fazem-nos rir, mas nada acrescentam à filosofia; pelo contrário, humilham-na, ao retratá-la

\footnotetext{
${ }^{2}$ Sobre este assunto, impõe-se a leitura atenta de Goulet-Cazé 1993.

3 "Se não perdes uma coisa, tens essa coisa; não perdeste os cornos, portanto, tens cornos" (7.187).
} 
como um actividade alienante se não mesmo pateta, quando os seus resultados contradizem tão abertamente o senso comum. E, todavia, não deverá haver maior inimigo do trabalho filosófico do que precisamente o senso comum, essa chora $[\chi \omega ́ p \alpha]$ que acolhe tudo o que não queremos ter de fundamentar nem admitir crido.

Esta intransigente defesa do óbvio harmoniza-se com o filão democrático no kinismo. O "todos podem cozinhar" de Gusteau (Ratatui [2007], Brad Bird) torna-se aqui no diogénico "todos podem filosofar". Ao homem comum

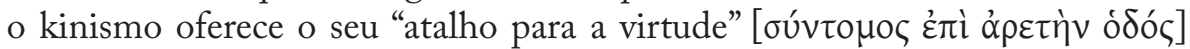
(7.121), como lhe chamou Apolodoro de Seléucida na sua Ética, porque se dispensam os longos estudos requeridos pelas outras escolas, apesar de se exigir um empenho violento. Como sintetizava Antístenes, "a virtude resulta das obras, não necessita de muitos discursos ou lições” (6.11). Goulet-Cazé explicita as consequências desta abordagem no seu verbete acerca do kinismo no Brill's New Pauly: "from this point of view the concept of the intellectual elite became meaningless: everyone could preach philosophy in public places" (2003a 1056). Mais tarde, no Império, esta abertura levaria à multiplicação dos (falsos) kínicos, de quem tanto se queixa Filosofia nos Fugitivos (12-13), de Luciano, ela que refere explicitamente que a opção fácil pelo manto e alforge de Diógenes se deve ao facto de "tudo quanto é necessário para [exercer] esta profissão [a filosofia] exigiria longo tempo". O kinismo surge como a única alternativa viável, porque rápida (e perigosamente exterior), para o homem comum, cansado de uma vida pobre, de trabalho e opressão.

Regressemos, contudo, às duas crias com que abrimos o penúltimo parágrafo. Diógenes teria sem dúvida contribuído mais para a história da filosofia se tivesse procurado demonstrar os erros lógicos que poluem cada um dos paradoxos expostos. Sirva Platão como contra-exemplo: do seu confronto com a escola eleática resultou o Parménides e o Sofista, e mesmo o aparentemente desprezível silogismo de Eubulides ecoa com proveito nas divisões político-biológicas iniciais do Político (cf. 265b6-265d5). Diógenes, se não responde aos seus interlocutores, ou é porque não sabe ou porque não quer (ou as duas coisas). Ele deliberadamente escusa-se a entrar em querelas racionais (isto é: no plano da razão); é um inimigo desonesto, que ataca pela retaguarda: o corpo, a matéria, o físico. Aos edifícios especulativos contrapõe a sua experiência directa do mundo, ostensivamente ignorando a falibilidade desta. Dir-se-á talvez que ela falha como instrumento de conhecimento mas que os kínicos não aspiram ao saber. Para o que pretendem - a vida mínima - as informações dos sentidos satisfazem: a natureza é sábia e desenhou o corpo armado para a sobrevivência.

Há, porém, outra possibilidade de fundar a sua atitude, bem mais interessante: a incapacidade da razão em capturar o que Feyerabend, um kínico 
moderno, na sua última obra, inacabada, chamou "a abundância do real". A recusa kínica da razão pode assentar nesta posição meta-filosófica forte, na ideia da impossibilidade de o Homem emoldurar e expor a realidade num sistema teórico organizado e final (Sloterdijk fala também disto: Parte II, II.A.6). Contra Hegel, Diógenes exclama: nem todo o real é racional. Uma parte da experiência humana permanece intraduzível, o esconderijo, talvez, do dado, sobre o qual a razão trabalha. A presunção da razão de ser auto-suficiente surge assim exposta como falsidade: os kínicos riem-se como os sentidos no conhecido fragmento de Demócrito (B125 DK). O kinismo teria percebido o quixotismo do discurso racional, o carácter utópico do seu projecto de descoberta comum do real, que faz tábua rasa, afinal, do ponto único e próprio sobre o qual o pensamento da cada Homem se levanta, da fenomenologia individual a que ele procura responder. Esta a necessidade que, por sua vez, Diógenes ignora e que não autoriza o seu corte com a filosofia. Dioniso tem de ser sempre filtrado por Apolo: quando, na sua defesa, Sócrates afirma que uma

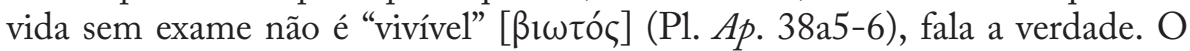
Humano não consegue acolher tout court a multiplicidade do real, que pela sua polimorfia se lhe apresenta monstruoso. A contemplação da realidade nua, na sua efervescência, impede a acção e o sentido. A atitude teológica (no sentido que damos ao termo: aquilo que é im-posto de cima, fruto de um esforço sistemático da razão, para iluminar e ordenar a experiência) de toda a filosofia não é um pecado, mas tão-só um produto da nossa contingência: só para os deuses, como percebeu Heraclito, tudo pode ser bom e belo (B102 DK). O Humano não pode saber sem, como Ódin, entregar um olho - e ver menos, num exercício voluntário, mas necessário, de cegueira. Não se pode afirmar sem negar: uma posição é uma o-posição e o Homem tem opiniões - não pode deixar de as ter: tem de viver e é legítimo que o tente fazer com coerência (quase nunca alcançada, porém, precisamente porque contra a fixação da filosofia em teologia pura se mobiliza a criatividade báquica das coisas). $\mathrm{O}$ real pode até ser contraditório, mas nós não podemos viver relaxadamente cindidos. O kinismo intui a alienação que toda a filosofia comporta e de que são representantes máximos os eleatas ou Berkeley (por isso se prestam mais facilmente ao gozo). Porque ignora necessariamente uma parcela do real, ela não pode deixar de, sobre esta, exercer violência, de onde o medo justificado de Diógenes. O filósofo recusa, porém, ver-se ao espelho: o kinismo não é menos violento nas suas exigências, no quinhão da experiência humana que sacrifica em nome da 'natureza', essa natureza aparentemente tão óbvia (contra a outra, escondida, de Heraclito [B123 DK]) que dispensa toda a investigação porque está aí, imediata.

Há no kinismo uma inocência perigosa e a violência dos puros. Quer deitar-se abaixo a filosofia ("aussi rejette-t-il toute spéculation logique, physique 
ou métaphysique": Goulet-Cazé 1999 670), para pôr no seu lugar um outro tirano amputado: uma natureza singularmente entendida, pobre, onde não há espaço para o especificamente Humano. Se assumirmos que falha a tentativa de explicar a desistência kínica da razão em termos de não-compactuação com a redução mentirosa do real que esta [a razão] opera necessariamente, então, parece-nos, aquela [a desistência kínica da razão] só se pode compreender no âmbito do mantra kínico do regresso à natureza ${ }^{4}$ : a razão não seria natural, daí ser alvo da censura kínica. Esta posição, porém, incorre na falácia naturalista que Hume identificou. Quando Platão diz que Diógenes é um Sócrates enlouquecido (6.54), descreve-o filosoficamente: ele abdicou da razão e fez dessa decisão o núcleo da sua posição.

O kinismo não é uma revolta contra o idealismo (para isso temos Demócrito ou Aristipo), mas uma sublevação contra a filosofia. Recordemos que Salústio, o último dos kínicos de que temos notícia, conseguiu fazer um dos alunos de Proclo abandonar a filosofia (Suda A3142 e A735). O ensino magistral não foi poupado por Diógenes, num dos seus mais divertidos jogos de palavras: "a escola de Euclides dizia ser uma es-cólica e o estudo com Platão um es-tédio" (6.24). O kínico, aliás, parece, como já Antístenes, ter encontrado em Platão um alvo preferencial, atacando os seus longos discursos: "Gozava com ele [dizendo que era] como uma matraca [um falador sem fim: aperantologos; a palavra, parece-nos, brinca, ainda que obliquamente, com pera: Platão é o falador sem alforge, o não-kínico: não conhece o laconismo da escola]" (6.26 in fine). Mais: "E de que ajuda para nós pode ser um homem [Platão] que, filosofando já há tanto tempo, não perturbou ninguém?” (Stob. 3.13.68). A crítica mais rotunda à filosofia nos seus moldes clássicos surge, porém, na resposta de Diógenes a um crítico (testemunho da dificuldade de já alguns contemporâneos em classificar a Lebensweise kínica como uma filosofia proper): "a alguém que lhe dizia «Tu filosofas, nada sabendo», respondeu: «Se acaso apresento uma sabedoria fabricada [aqui no sentido de "não-verdadeira";

${ }^{4} \mathrm{O}$ lema kínico esconde, na realidade, um conjunto de práticas que, de natural, nada têm. Não é, porém, este o espaço para analisar a ascese kínica e o ódio professado do movimento ao prazer (chamar ao kinismo, como fazem vários, um hedonismo é vê-lo apenas por metade, para esquecer o que nele perturba os seus apologistas modernos, que, por exemplo, parecem não reconhecer a semelhança entre a mortificação cristã e a via kínica, ambas, para recuperar a expressão repetida de Goulet-Cazé [e.g. 2003b 9], "exercícios físicos com finalidade moral”). Limitamo-nos a ecoar aqui o juízo senequiano (Cartas a Lucílio 5.4-5), e lembremos que o filósofo era amigo de Demétrio, o kínico: "O nosso objectivo é, primacialmente, viver de acordo com a natureza. Ora é antinatural torturar o próprio corpo, repelir os cuidados elementares de higiene, procurar a sujidade e tomar alimentos não apenas humildes mas repugnantes, repelentes" (trad.: Segurado e Campos 2009).

${ }^{5}$ Procurámos, possivelmente sem sucesso, manter algo do jogo de palavras original entre schole, "escola", e chole, "bílis", e diatribe, "tempo gasto com" ("passa-tempo", em sentido radical), de onde "estudo", "lição" e "escola", e katatribe, "perda de tempo". 
poderíamos também, recuperando o elo entre poiesis e mimesis, traduzir por "imitada", com toda a conotação também de falsidade que transporta: talvez mesmo "simulada"], também isso é filosofar»" (6.64). O filósofo, não o poeta, aparece aqui como um fingidor (philosophein é traduzido de forma directa por Diógenes como prospoioumai sophian) e a actividade dos pensadores denunciada como tuphos, "ilusão" se não mesmo "mentira".

Para o kínico, pelo contrário, como já foi dito, não são necessárias “instrução, exposições [magistrais] ou outras patetices” (Luc. Vit. Auct. 11) para alcançar a virtude kata physin, também porque, de facto, não há lugar para a razão na natureza, se entendida como o espaço de que o Homem se autonomizou (nessa autonomização constituindo-se como Humano). Regressar à natureza, como querem os kínicos, implica por isso castrar o Homem - reduzi-lo ao Cão. A lei, a convenção, o costume, o nomos, é precisamente aquilo que, no dizer do Estrangeiro Ateniense, nos distingue dos animais mais selvagens $(\mathrm{Lg}$. 9.874e9875a1). O facto de a lei ser arbitrária (no sentido de 'variável') não serve para a rejeitar como falsa; pelo contrário: é por não ser absoluta (diferentemente da natureza, cujas exigências não podem ser desobedecidas) que se revela como o espaço da liberdade actual e activa do Homem, contra a necessidade própria do mundo material. A lei podia ser diferente e por isso todo o nomos exprime uma vontade que humaniza.

Goulet-Cazé, que, como muitos outros, por Nietzsche se afirmar como neo-kínico apresenta Diógenes como proto-nietzschiano, sublinha fortemente o motivo da vontade na filosofia kínica, mas isso resulta da incompreensão da estrutura da liberdade humana e da incapacidade de perceber que o kinismo assenta sobretudo na domesticação da vontade, advogando a repressão ou pelo menos a abdicação do desejo contra a pleonexia natural do Homem. Esta, porém, não é a melhor crítica: é preciso partir dos mesmos pressupostos que os kínicos para pôr a nu as contradições internas do 'sistema'. Há, pois, que assumir que o Humano deseja tão-só aquilo que a natureza lhe exige: o mais é uma criação social. Esta ligação entre o desejo e o natural é, porém, fortemente problematizada pelo kinismo, na medida em que não é assumida como um dado. Não basta, de facto, reconhecer o que é necessário, é importante querê-lo: não chega conhecer o bem, há também que o desejar. Esta ênfase na vontade, em ruptura com o intelectualismo socrático, Goulet-Cazé descobre-a em Antístenes (1999 688 n. 5 [comm. ad 6.11]). Este exercício volitivo que o filósofo exige para que vivamos de acordo com a natureza coloca em questão a própria ideia kínica de physis: como pode o regresso à natureza implicar um esforço tamanho? A própria dificuldade em cumprir com o objectivo revela-o como, afinal, não-natural ou apenas - e aqui está o busílis da questão - tão natural quanto outras vidas vendidas também como naturais e que exigem igual esforço daqueles que querem viver de acordo com elas. É impossível 
eludir o confronto de filosofias aqui latente, de justificações da opção por esta ou aquela vida, de porque é que esta é mais natural ou menos - e, neste campo do rationale da escol(h)a, como observámos, o kinismo tem pouco para oferecer, partindo em clara desvantagem, mau grado as reconstruções que têm sido feitas do pensamento dos cães. A 'natureza' (ela mesma um conceito histórico produto de um esforço de abstracção) dos kínicos mostra-se tudo menos óbvia e um produto, como outros entendimentos dela arriscados ao longo do tempo (até o nosso: isto, em si, não é problemático; é-o esquecermos a sua forma teórica e, como os kínicos, insistirmos na 'obvicidade' do conceito que não reconhecemos como tal).

Esta argumentação peca por resvalar para o erro que procurámos evitar: o não enfrentar o kinismo em casa. Temos que aceitar não só que o Humano apenas procura aquilo que a natureza requer (ele é franciscano nos seus desejos) mas também que os kínicos acertaram no que esta pede (não servindo a dureza de viver segundo a regra kínica como desculpa para suspeitar que Diógenes e amigos falharam em perceber o que a natureza exige). Há, então, que postular que o nosso querer está profundamente corrompido pela sociedade e que, por isso, é necessário reconquistá-lo na sua pureza original por um acto de vontade: é preciso querer querer. Este querer original (o segundo) aparece-nos alinhado com a natureza - nisso, porém, esquecendo-se como querer: sinto necessidade de cagar, cago; preciso de libertar sémen, masturbo-me. Querer querer significa aqui não adiar ou reprimir os desejos naturais que me sacodem, aceitar cumprir com eles no momento. Isto não pode ser lido, como o fazem tantos, em chave nietzschiana, como um exercício perfeito de revelação da vontade: tal visão assenta numa incompreensão da estrutura dialéctica da coisa.

Primeiro, há aquilo que há que: a necessidade. Aqui, porém, no domínio puro do que tem que ser, o Humano não se pode manifestar. Avancemos, então, para a negação da tese: a afirmação pura da vontade. Esta, porém, acaba por se revelar apenas um outro tipo de necessidade, porque se torna ela mesmo imperadora: quero - faço. Só no momento final, na negação da negação, esta oposição é superada-suprimida (aufgehoben) na capacidade especificamente humana de não querer o próprio querer (o que implica a mediação do querer por outra instância: a razão). A solução kínica pára na antítese: Diógenes contenta-se com a afirmação simples do seu querer. $O$ facto de satisfazer as suas necessidades biológicas em público permite-nos dizer que ultrapassa o primeiro nível dialéctico: tendo de comer, ele escolhe ir comer para a ágora. É difícil acreditar que esse fosse o sítio onde rotineiramente lhe desse súbita a fome e que ele se limitava a aceder na hora ao pedido do corpo: antes é de crer que, dirigindo-se para o mercado, quisesse com isso publicitar a sua aceitação pacífica dos imperativos somáticos. Ao tomar, porém, como objecto do seu querer o que tem de ser, esse objectivo sai em boa medida frustrado, pois que 
o querer que ali se afirma é demasiado precário (o que tem que ser acabaria sempre por se impor - por ser), distante do querer livre (quase perigosamente arbitrário) que se associa ao segundo degrau dialéctico.

Para se perceber o que aqui dizemos, confronte-se a atitude kínica com o sim do herói trágico, também ele, superficialmente, um assentimento ao que tem que ser, mas um tem que ser que aparece como uma inevitabilidade desejada ab-solutamente pelo protagonista. A mediação racional possível na síntese falha, porque a razão nada pode dizer perante a situação que é chamada a julgar, empurrando a sua resolução para a vontade desamparada, que, porque fundamentalmente afirmativa, vai tender à acção mais do que à passividade. Orestes pode matar a mãe ou desonrar o pai e nenhuma opção é moralmente superior à outra: ambas são igualmente más (ele percebe-o: daí a sua hesitação, daí a razão para o deus ex machina via Pílades: só os deuses podem destrinçar o nó). Orestes quer e quer apenas: nenhum outro critério pesa na sua acção, se reduzida à escala humana, e nenhuma possibilidade de acção que se abre à sua frente tem, por si só, que ser. Isto é algo muito diferente do que observamos nos kínicos, cuja vontade corre contra (nisso, paradoxalmente, na direcção de) a necessidade (há quase um desejo de negar que a necessidade seja necessária, para afirmar a liberdade, exactamente o contrário do que assistimos na tragédia, que abraça a ananke).

É sintomática, a este propósito, a morte de Diógenes, como a narram os seus admiradores, que demonstra como o kinismo acreditou na sua solução, que a mesma estória prova falsa, de que é possível querer o que tem que ser (e nisso fazer gala de liberdade). Diógenes teria voluntariamente abdicado de respirar. Fora isso possível, então poderia dizer-se que o apelo kínico a querer as coisas da natureza fazia sentido, pois então estas, afinal, não teriam que ser, isto é, não seriam imperativas. Não é, contudo, isso que sucede: ninguém pode optar por não respirar. Na impossibilidade da lenda kínica descobre-se a realidade da insuficiência da sua proposta moral de querer o que tem que ser, que obscurece o Humano, porque o rouba no que lhe é mais próprio (o que parece ser uma constante da escola de Diógenes).

\section{$\S 2$}

"Os kínicos não eram nenhuns anacoretas; o seu estar-consciente [Bewußtsein] encontrava-se ainda essencialmente [wesentlich] em relação com outro estar-consciente. Antístenes e Diógenes viveram em Atenas e apenas aí poderiam ter existido". Esta observação de Hegel, das Lições supracitadas (1975 557), põe a nu a falácia da autarkeia kínica, expondo o paradoxo de esses filósofos que tanto apregoavam o regresso à natureza nunca o terem de facto feito. Dir-se-á que o sentido do lema kínico é outro: um grito de guerra contra tudo o que é falso entre os Homens. Há, porém, que 
desimplicar as consequências desse apelo. O Estrangeiro de Eleia no Político de Platão interroga-se a dado momento (261d) sobre a natureza do Humano: somos seres de criação individual ou colectiva? Se o Homem é, como dizia Aristóteles (Pol. 1253a3), um ser político, que vive em comunidade, a atitude kínica não pode senão deixar-nos perplexos, assente que está na recusa do cosmos social. Denunciar a violência que subjaz a esta ordem é penetrar no paradoxo de uma natureza que reclama a sua própria ultrapassagem. Pretender que ela [a violência] pode não existir é uma ilusão de que a História nos ensinou a desconfiar, pois quantos foram impelidos por essa boa-intenção traíram-na para pretensamente a cumprir. Abdicar, por sua vez, da co-existência humana para manter a pureza moral, é desistir do Homem enquanto tal, se ele é chamado à relação: uma atitude destas assenta na lógica totalitária do tudo ou nada (e intuímos já aqui o radicalismo explosivo do kinismo). Se, pelo contrário, o Humano é fundamentalmente um animal solitário, se essa é a sua verdade, então não se percebe porque insiste o kínico em habitar na cidade em vez de, como Thoreau, ir "to the woods [...] to live deliberately, to front only the essential facts of life" (1966 74). Poderíamos argumentar que ele procura pelo seu exemplo inspirar os outros, mas, apesar de Diógenes ter tido os seus discípulos, não nos parece residir aí a razão para a sua permanência em Atenas e Corinto. De facto, não encontramos nele o cuidado socrático com o outro, o interlocutor, a cuja personalidade a conversa se deve adaptar de modo a permitir a sua conversão à filosofia: Diógenes é bruto, directo e universal (o que Séneca reprova na Carta 29.1).

Hegel acerta quando deriva a urbanidade do kínico da necessidade de reconhecimento. $\mathrm{O}$ kinismo pertence mais a uma história da performance do que da filosofia: requer uma plateia, tem mais que ver com o punk do que com Kant. O paroxismo do espectáculo é atingido com Peregrino, que se suicidou em público, nos Jogos Olímpicos de 165. "[Diógenes] dizia que a maioria [das pessoas] estão a um dedo de distância da loucura: quem caminhe com o [dedo] do meio esticado, é tido por louco; [mas] ninguém [que caminhe] com o indicador [esticado o é - curiosamente, a pose de Platão na Escola de Rafael.]" (6.35). Este aforismo interessa-nos a vários níveis, demonstrando como o kínico joga com os mesmos códigos a que se opõe, nisso provando a sua dependência deles. O kinismo distingue-se frontalmente das vanguardas artísticas do começo do século (excepto o dadaísmo, cujos elementos kínicos Sloterdijk explora com alguma atenção: Parte II, IV.2) por, ao contrário destas, ser sobretudo oposição, assumindo contornos reactivos. Todo outro é o caso do futurismo ou do expressionismo que, rompendo drasticamente com os códigos estéticos burgueses herdados do século anterior, são acompanhados de uma visão própria sobre a arte e o Homem, que publicitam em manifestos. O kinismo, pelo contrário, tem pouco para oferecer: Diógenes espojado a gozar o sol captura a passividade da 
apatia kínica, em que o otium nem para filosofar é utilizado. Diógenes só age para chocar - mas e quando se convertesse toda a cidade ao kinismo? Teríamos uma comunidade de Homens supostamente perfeitamente livres, mas em que se ocupariam, se não há espaço para o trabalho, as artes, a filosofia ou a ciência? Diógenes não é Lafargue (ou Agostinho da Silva). A vida do deus, que o filósofo nos propõe, é um completo aborrecimento. O kínico, de novo, demonstra não ter investigado até ao fundo a condição humana: "no princípio era a acção" (Goethe, Fausto 1237). O Homem, como os putos, quer fazer coisas.

Quando Diógenes se passeia a mostrar o dedo não há nisso uma qualquer tomada de posição positiva, ao contrário do corte de cabelo e saias das flappers nos anos 20, e muito menos a ingenuidade de um Mr. Bean em LA. Diógenes ataca um último santuário do propriamente humano: o simbólico (o Homem, como ensina o Aristófanes de Platão, é ele mesmo um símbolo: Smp. 191d4). Assim também Crates: "Chamando por causa de um assunto qualquer o gimnasiarca, agarrou-se às ancas dele. Tendo-se este irritado, replicou: «E então? Não são também estas [ancas] tuas, tanto quanto os joelhos?»" (6.89). O 'obvio-ismo' dos dois filósofos não permite às coisas serem mais do que são: também elas são condenadas à pobreza. Não espanta pois o seu desdém pelas artes, que operam no registo do símbolo. E, porém, como dito, Diógenes está perfeitamente ciente dos códigos que questiona e do seu estatuto qua códigos: depende deles para existir qua Diógenes. O homem que prega a naturalidade foi o que mais activamente trabalhou na construção de uma personagem.

A acusação platónica de que Diógenes era tão orgulhoso como aqueles que criticava, acusação ecoada pelos escritores cristãos, toca nervosamente na verdade do caso. "Uma vez," - conta Laércio - "tendo Platão convidado [para ir a sua casa alguns] amigos vindos da parte de Dionísio, pateando as tapeçarias

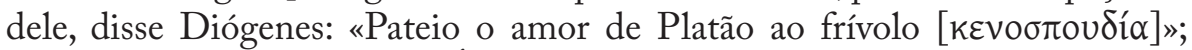

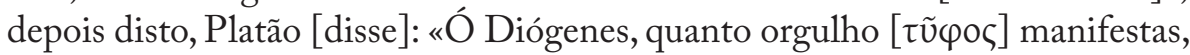
pensando não te orgulhares». Alguns afirmam que Diógenes disse: «Pateio o orgulho de Platão», e este disse: "Com outro orgulho, Diógenes»" (6.26) Note-se que Diógenes não pretende que Platão mude de vida, o que poderia fazer falando com ele em privado ou, a agir como agiu, em qualquer altura. Ele espera, porém, por que cheguem os amigos de Platão e é à frente destes, para este público, que, porque estrangeiro, não o conhece e ainda se deixa escandalizar, que Diógenes pretende humilhar Platão. Ele vai à procura de espectadores: daí o seu local por excelência ser a ágora. O paroxismo da veia teatral dos kínicos atinge-se com Menedemo/Menipo (vide Goulet-Cazé 1999765 n.

\footnotetext{
${ }^{6}$ Registe-se uma anedota semelhante em relação a Antístenes: “Tendo voltado o rasgão na sua roupa [e pondo-o] à vista, Sócrates, vendo-o, disse: «Vejo o teu amor à opinião através do rasgão»" (6.8).
} 
1), ele que anda, conta Laércio (6.102), com toda uma fantasia e até coturnos. Outras estórias, que podemos sempre descartar como criações dos opositores do kinismo, mas que testemunham uma inquietação verdadeira, comprovam a sedução de Diógenes pela glória: “...veio a Delfos não para perguntar se

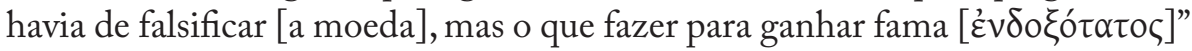
(6.21). O seu tango com as convenções é tanto mais escandaloso quanto, por vezes, ele recorreu a elas em seu favor: "um dia, tendo ido a um simpósio de jovens, com a barba meia-feita ${ }^{7}$, segundo conta Métrocles nas Anedotas, levou pancada; depois, tendo inscrito numa tabuinha [que levava] dependurada os nomes dos que lhe haviam batido, deu umas voltas [pela cidade], até, pela sua bybris, [os jovens] serem acusados e censurados de todos os lados" (6.33; cf. 6.89 in fine). Diógenes conta com a reacção social a seu favor (ele sabe-se amado: 6.43) e opera com um produto cultural como o conceito de bybris.

É já bastante explícito como este comportamento de Diógenes trai a sua pretensão à auto-suficiência, mas importa levar a cabo uma crítica mais profunda ao conceito de autarkeia: primeiro, porque a teoria de um filósofo deve ser julgada pelos seus méritos intrínsecos e não tanto pela capacidade do seu criador em ser coerente com ela; segundo, porque o ideal em questão não é exclusivo dos kínicos, ainda que estes o tenham levado ao extremo. Tal crítica não pode senão assumir a forma de um embate teológico, de uma discussão sobre a im-provável natureza do Homem. Todavia, a nossa posição tem de ser explicitada, para que o confronto possa existir e não apenas estar prometido ou adivinhado. Como o Estrangeiro de Eleia no Político, estamos convencidos de que o Homem é um animal de criação colectiva: é em comunidade, para começar, que ele aprende a língua (uma convenção - a não ser que sejamos adeptos do cratilismo - de que Diógenes nunca se desembaraçou, ao contrário dos dadaístas ${ }^{8}$ ) e com ela a pensar (logos é "discurso", mas também "razão"). O Humano é pois em grupo que adquire a possibilidade do exercício do que há de mais distintivo nele: não é um acidente que, ainda no Político, após o corte na diérese inicial que o classifica como animal de criação colectiva (261d3-261e7), o que se lhe segue, levado a cabo por Sócrates, o Jovem, assente precisamente na distinção inteligente|não-inteligente: é que os dois estão apaixonadamente ligados. O ser-em-relação precede e permite o ser-em-razão. A simples capacidade para o discurso, mesmo sem considerar as condições da sua actualização, aponta para a realidade comunitária do Humano: quem fala,

\footnotetext{
${ }^{7}$ Note-se que este era o castigo entre os espartanos para os desertores. Diógenes, portanto, recupera aqui códigos sociais para se identificar voluntariamente com os cobardes. Reler, para apreender o alcance do gesto, a secção de Sloterdijk sobre o cinismo militar (Parte II, II.A.1).

${ }^{8}$ Ainda que seja necessário sublinhar como os kínicos manipulavam a língua com grande liberdade, sendo famosos os seus trocadilhos. Há nisso uma certa desconstrução da linguagem em acção.
} 
dirige-se a alguém: o logos só acha a sua verdade (e a verdade) em dia-logos. Platão percebeu-o com clareza e por isso se recusou a escrever um tratado. O próprio Aristóteles, no encómio ao sábio auto-suficiente no Livro X da Ética a Nicómaco, admite que este, apesar de tudo, trabalha melhor na companhia dos seus co-laboradores (1177a34).

O kinismo, porém, não é um epicurismo, que sempre reconheceu que a vida boa implica um pequeno número de companheiros. Diógenes, pelo contrário, pretende imunizar-se contra todas as voltas e contravoltas da fortuna (esse, diz, o maior ganho que tirou da prática da filosofia: 6.63) e, para isso, como o médico cartesiano, para curar uma constipação corta o nariz. Há quem afirme que a atitude do filósofo era propositadamente exagerada e que, por detrás do seu teatro, há uma mensagem válida, um apelo à indiferença para com tudo o que é efémero, sob pena de a nossa felicidade, se projectada nesses objectos exteriores (coisas ou pessoas), ser posta em causa com o possível desaparecimento destes. Não seria necessário abraçar a pobreza e romper os laços com o mundo, mantendo relações apenas a uma distância segura, mas sim ter tudo em liberdade, para que o móbil das nossas acções não se reconduzisse a nada fora de nós. Face à perda do que nos era útil ou mesmo querido deveríamos saber reagir com a paz de Diógenes ante a fuga do seu escravo (6.55).

Todavia, porque uma pregação assim se arriscaria facilmente a parecer cínica (quem acreditaria em quem falasse deste modo mas vivesse numa villa luxuosa?), Diógenes defende a verdade do seu credo pelo seu exemplo (este é, a dado ponto, o argumento de Sloterdijk: 2011 219). Uma ou outra anedota parecem apontar nesse sentido: "Tendo sido interrogado sobre se os sábios comiam bolinhos $[\pi \lambda \alpha \kappa o \tilde{v} v \tau]$, respondeu: «[Comem] todas as coisas, $<$ mas não> como os restantes Homens»" (6.56). Há quem veja o episódio como um testemunho de que, no kinismo, não estamos perante uma apologia moral da pobreza (é bom ser pobre, porque "deles o Reino"), mas sim perante uma filosofia da libertação que implica, para que não se esteja dependente de nada, que se viva com o mínimo (a pobreza como meio, não como fim). Se, porém, o kínico encontrar algo à mão-de-semear (como um bolinho) não se coibirá de o comer, precisamente porque a perspectiva não é moral: ninguém está aqui, por exemplo, a combater a gula. Insultar os kínicos como parasitas é não compreender que para eles é irrelevante o que comem: é esta atitude de desprendimento que permite a Diógenes dizer que o sábio come tudo mas não como os outros Homens. $\mathrm{Na}$ mesma linha ainda de interpretação da pobreza kínica em termos de caricatura de uma proposta válida, de indiferença face às coisas, atente-se no que escreve Laércio: "[Diógenes] dizia imitar os maestros dos coros, pois também estes davam [a nota] um tom acima, para os restantes atingirem o tom certo" (6.35). Seria difícil arranjar uma declaração que mais beneficiasse uma interpretação generosa do radicalismo dos kínicos, ainda que 
possamos também convocar o aviso de Métrocles: "a riqueza é prejudicial, se

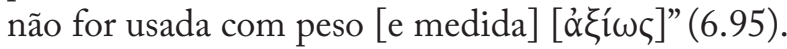

Contudo, é significativo que o elemento da pobreza tenha ficado embebido no nosso conceito do kínico, ao ponto de só reticentemente estarmos dispostos a atribuir esse nome a quem, como o personagem anónimo acima invocado, vivesse no meio do conforto, por mais indiferente que fosse a este. Não podemos domesticar o kinismo com essa facilidade - e temos boas razões para oferecer resistência a essa tentativa. De acordo com Eliano ( VH 4.11), por exemplo, Sócrates era criticado por Diógenes pelas suas sandálias, a que Platão se refere no Banquete (174a4), bem como por outros itens desnecessários de que não se havia desembaraçado (a começar pela sua própria casa). Diógenes, de facto, não conhece o desprendimento de Aristipo: «o cerne da doutrina deste consiste em desprezar todas as coisas, mas servir-se de todas elas, e de todas retirar prazer» (Luc. Vit. Auct. 12). O kínico não o consegue aceitar: Diógenes criticou Aristipo por frequentar a corte de tiranos. Para ele, o dinheiro (e o poder) são inevitavelmente fonte de miasma: não é possível uma convivência descomprometida com tais coisas. Só essa posição dogmática (mas que carece de justificação) pode absolver Diógenes do embaraçoso episódio com Aristipo, quando, encontrando-se ambos a tomar banho, Aristipo, o primeiro a sair, pegou no manto de Diógenes, deixando-lhe, para se vestir, a roupa púrpura que era a sua. $\mathrm{O}$ kínico, porém, recusou-se a isso, ao que Aristipo não pôde deixar de notar o quão pouco livre Diógenes, no fim de contas, era, ele que, afinal, não sabia viver com o que tinha à mão, de tal maneira estava preso à sua personagem (a estória é narrada, entre outros, por Horácio nas suas Cartas 1.17). A anedota mostra como a pobreza era uma questão de honra para os kínicos, a ponto de, por ela, atropelarem outros valores da escola.

Aceitemos, porém, a leitura benévola do magistério de Diógenes, anteriormente exposta. A sua ideia de liberdade continua, ainda assim, a suscitar a nossa oposição. De facto, o problema principal mantém-se: a negação do Humano como ser relacional. Diógenes pode ser imune a todos os volte-faces da fortuna porque se refugiu num solipsismo prático. Com isso, contudo, repudiou um traço básico da condição humana. A apatia kínica diverge num ponto crucial da indiferença cristã: o cristão acabado desliga-se também, num certo sentido, das vicissitudes da existência humana (ainda que indiferença não seja aqui apatia), mas consegue essa abstracção final das peripécias da vida porque se apoia (e verdade, em hebraico, quer dizer isso mesmo: "suporte/ sustento") noutra pessoa: o deus-homem Cristo. A sua independência revela-se afinal como dependência. Pouco importa que para o não-crente esta não tenha um objecto real, pois para o fiel, subjectivamente, ela é verídica e cumpre a necessidade de relação no Homem. O kínico, pelo contrário, cortou os laços todos que o pudessem de alguma maneira prender e heterodeterminar. 
Ele vive "sem [s]e aproximar nem de um amigo nem de um estrangeiro, pois essas relações são o fim do [s]eu império"(Luc. Vit. Auct. 10). Importa aqui lembrar o falado cosmopolitismo kínico, que é hoje quase consensual dever ser entendido negativamente: "as a citizen of the whole world the philosopher is actually a citizen of nowhere" (Goulet-Cazé 2003a 1058). Só assim, de resto, se compreende que Teles, por exemplo, tenha escrito um Sobre o Exilio em que louvava as vantagens em ser expulso da cidade-mãe: o que se procura aqui é um sentido de não-pertença, a que é associada a liberdade. O kínico reclama ainda a dissolução dos laços privados: Diógenes surge-nos um crítico consistente do casamento (e.g. 6.29) e apela à cessação da procriação: as crianças só trazem preocupações, com a necessidade de as educar, o que limita a liberdade dos pais. «Não te preocuparás nem com casamento, nem com filhos, nem com pátria, coisas que, todas elas, considerarás como grandes tolices» (Luc. Vit. Auct. 9): este o mandamento do kínico.

Torna-se aqui clara a sua fundamental incapacidade para aceitar a fragilidade humana (que decorre da nossa dependência), dado base da nossa natureza (sejam-nos desculpadas as repetidas referências a esta como avisámos, teológicas, porque, paradoxo, síntese de uma experiência fenomenológica incomunicável -, mas a nossa divergência com o kinismo radica em última análise num dissenso antropológico que não podemos omitir). Os gregos perceberam bem, e essa uma das suas grandezas, o estatuto precário do Humano, a que chamaram o mortal: ho brotos (a morte é a actualização extrema da fragilidade que nos constitui). Martha Nussbaum elaborou com mestria esta intuição no seu The Fragility of Goodness, chamando a atenção para como a bondade implica a exposição à possibilidade de ser (moralmente) destruído. Algo de semelhante se poderia dizer da felicidade: a tragédia implica precisamente a possibilidade de uma situação em que esta não exista como opção. A felicidade estaria, pois, associada a um conjunto de condições nem sempre sob o controlo do sujeito e, uma vez abolidas ou violadas, impossíveis de reconstituir, impedindo o acesso ao estado anterior de felicidade. Para o grego, é impensável um Príamo sobrevivente de Tróia que recuperasse a felicidade: ele havia-se investido totalmente nos seus filhos e na sua cidade. A sua desgraça é, pois, completa e Príamo inconsolável: não há deus que o salve. A felicidade é uma coisa frágil (mas também por isso tão preciosa), abertamente dependente dos outros e do que estes venham a fazer (as mónadas de Leibniz são uma má fantasia). Aristóteles, no Livro I da Ética (1100a10-30), analisa a opinião de que certos acontecimentos (como o destino da casa ou uma damnatio memoriae póstuma) podem, mesmo após a morte de uma pessoa, ainda afectar a sua felicidade. O filósofo rejeita esta possibilidade como absurda, mas ela reflecte, de uma maneira extraordinariamente violenta, a precaridade da felicidade humana e a dimensão essencialmente relacional da mesma. $\mathrm{O}$ kínico ignora 
tudo isto, ao pretender afirmar-se como auto-suficiente, orgulhosamente só: engana-se a si mesmo com uma falsa promessa de felicidade, como Alex, em $O$ Lado Selvagem (2005, Sean Penn) - apenas para no fim concluir que, de facto, "happiness is only real when shared". 


\section{Bibliografia}

M.-O. Goulet-Cazé (1993), "Le cynisme est-il une philosophie?" in M. Dixsaut, ed. Contre Platon, I. Paris, J. Vrin 273-313.

___ ed. (1999), Diogène Laërce. Vies et doctrines des philosophes illustres. Paris, Librairie Générale Française.

__ (2003a), vox 'Cynicism' in H. Cancik - H. Schneider. - C. Salazar et al., eds. Brill's Nerw Pauly, III. Leiden/Boston, Brill 1052-1060.

___ (2003b), Les Kynica du stoïcisme. Stuttgart, Franz Steiner.

G. W. F. Hegel (1975), Vorlesungen über die Geschichte der Philosophie, I. Frankfurt am Main, Suhrkamp.

M. Marcovich (1999), Diogenes Laertius. Vitae philosophorum. Stuttgart, Teubner.

J. A. Segurado e Campos ( $\left.{ }^{4} 2009\right)$, Séneca. Cartas a Lucílio. Trad., intr. e notas. Lisboa, Gulbenkian.

P. Sloterdijk (2011), Crítica da Razão Cínica. Lisboa, Relógio d'Água.

H. D. Thoreau (1966), Walden; or, Life in the woods $\mathcal{E}$ On the duty of civil desobedience. New York, Holt, Rinehart and Winston. 